\title{
コード補正によるロータリエンコーダの高精度化
}

\author{
非会員 小目 五十司 (防衛庁海上幕僚監部) \\ 正員鈴 木 義 久 (防衛大学校) \\ 正員萩原述史 (防衛大学校)
}

\section{A Method of Improving the Accuracy of Rotary Encoders Using a Code Compensation Technique}

Isoji Ogura, Non Member, Yoshihisa Suzuki, Member, Nobumi Hagiwara, Member (National Defense Academy)

This paper describes a method of improving the resolution and accuracy of incremental type rotary encoders by interpolating the scale pitch interval using the phase encoding and code compensation system. Several interpolation methods have been proposed which stand on the assumption that the scale intervals are accurate. But the experiment on an optical encoder system revealed that the scale pitch intervals include error.

The interpolation method proposed in this paper compensates the error in the pitch intervals as well as the error caused by the nonlinearity of the detected signals. By applying this system to an optical incremental type rotary encoder whose scale pitch is $1 / 360$ rotation (1 degree resolution), finer than $1 / 45000$ rotation $(0.008$ degree) resolution has been obtained.

$$
\text { キーワード：エンコーダ、ロータリエンコーダ、角度測定、分解能、内挿法 }
$$

\section{1。まえがき}

回転角度の高分解能計測には、アブソリュート型あるい はインクリメンタル型ロータリエンコーダが用いられる。 前者は 1 回転において絶対角度を与えることができるのに 対して(1)，後者は絶対角度は与えないが高分解能化には適 している(2)。近年、ロータリエンコーダの高分解能化は、 工作機械の正確な回転角度あるいは位置の制御等の多くの 分野で求められている。ロータリエンコーダの分解能の向 上には、さらに微細なスケールを持つロータリエンコーダ

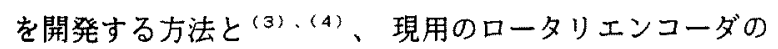
スケールピッチを内挿する方法とがある(2)、(5)。本論文 では後者の方法をさらに発展させ、既設のロータリエンコ 一ダに簡単な回路を付加することにより、その分解能を向 上させることを目的とする。

筆者らはこれまで、高分解能化の方法としてインクリメ ンタル型エンコーダのスケールピッチの中を内掩する位相 エンコーディング法を提案してきた ${ }^{(6)}$ 。また、その出力
に対してスケールピッチは正確であるという仮定の下にコ 一ド補正を実施してきた(7)、(8)。しかし、ロータリエン コーダ全周分のデータを分析した結果、ピッチの間隔には その回転軸の偏心等を原因とする誤差が存在することが判 明し、さらに角度測定精度を向上させるためにはこの誤差 は無視できないことが分かった。このため、ここではこの ピッチ間隔の誤差をも含めた新しいコード補正方法を提案 し、実際に装置を試作し回転角検出精度の検討を行った。

$$
2 \text { ，位相エンコーディング法 }
$$

インクリメンタル型ロータリエンコーダから出力される 2 相信号は、その䄳を無視すれば次式で表される。

$$
\begin{gathered}
V_{*}=V_{P} \cos K \omega t \quad \cdots \cdots \cdots \cdots \cdots \cdots(1) \\
V_{o}=V_{P} \mathrm{~s} \operatorname{in} K \omega t \quad \cdots \cdots \cdots \cdots \cdots \cdots(2) \\
\text { こで } V_{P} \text { は出力電压の大きさ、 } \omega \text { はエンコーダ軸の回 }
\end{gathered}
$$
転角速度、Kは1回転あたりのピッチ数である。この 2 相 信号を理想正弦波と考えリサージュ图を描かせると、2相 信号によって定められる点 $P$ は 1 に示すように円軌跡を 
描く。点 $P$ は、エンコーダ軸が 1 ピッチ回転する毎に円軌 跡上を 1 回転する。したがって、エンコーダの1ピッチを $2 \pi$ ラジアンの電気的位相空間に対応させることができる。 また、点 $P$ 電気的位相角 $\theta$ は次式で与えられる。

$$
\theta=\mathrm{ta} \mathrm{n}^{-1}\left(V_{b} / V_{0}\right)
$$

いま、 $(360 / K)^{\circ}$ の回転角に対応する $2 \pi$ ラジアンの 位相空間を $N=2^{n}$ 個の扇形のセクタに分割する。セク夕 には図 1 に示すように0〜N-1の番号をつけ、以後この 番号を位相コードと呼ぶ。

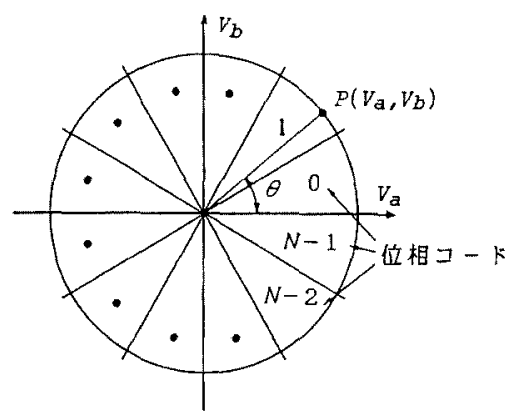

図 1 位相コード

Fig. 1. Phase code.

$\pi / 2$ ラジアン位相の異なる出力信号は、T秒ごとにそ

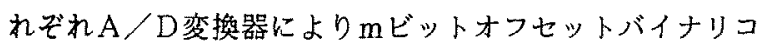

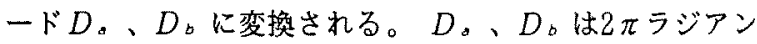
の位相平面を图 2 に示寺ように $2^{\mathrm{m}} \times 2^{\mathrm{m}}$ 個のセルに分割す る。V.、 $V_{b}$ が $\mathrm{A} / \mathrm{D}$ 変換器のフルスケール電圧の範囲 内であれば、D，D。によりセルが定まり、このセルの 中心位相角度 $\theta_{0}$ は (4) 式で与えられる。

$$
\theta C=\left\{\begin{aligned}
\tan ^{-1} \frac{D_{b m}}{D_{o m}}:\left\{\begin{aligned}
D_{0} \geqq 2^{m-1} \\
D_{b} \geqq 2^{m-1}
\end{aligned}\right. \\
\pi-\mathrm{tan}^{-1} \frac{D_{b m}}{D_{o n}}:\left\{\begin{array}{l}
D_{0}<2^{m-1} \\
D_{b} \geqq 2^{m-1}
\end{array}\right. \\
\pi+\mathrm{tan}^{-1} \frac{D_{b n}}{D_{a n}}:\left\{\begin{array}{l}
D_{0}<2^{m-1} \\
D_{b}<2^{m-1}
\end{array}\right. \\
2 \pi-\mathrm{tan}^{-1} \frac{D_{b n}}{D_{\mathrm{a} m}}:\left\{\begin{array}{l}
D_{0} \geqq 2^{m-1} \\
D_{b}<2^{m-1}
\end{array}\right.
\end{aligned}\right.
$$

ただし、

$$
\left\{\begin{array}{l}
D_{a m}=D_{b}-2^{m-1}+1 / 2 \\
D_{b m}=D_{b}-2^{m-1}+1 / 2 \\
D_{o n}=2^{m-1}-D_{0}-1 / 2 \\
D_{b n}=2^{m-1}-D_{b}-1 / 2
\end{array}\right.
$$

$\theta_{c}$ は特定の位相コードに対応するので、この位相コー ドをリードオンリメモリ（ROM）のD。、D。に対応した アドレス $2^{m} D 。+D 。$ に書き込んで拈けば、各サンプル周 期Tでサンプルされたディジタルコード D，、D。によっ てそれに対応した位相コード $P$ ；を直ちに読み取ることが

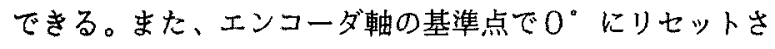

れるようなピッチ数を計数する可逆計数器の出力を $C$ ：と すると、これらは基準点を $0^{\circ}$ とする絶対角度を与える。

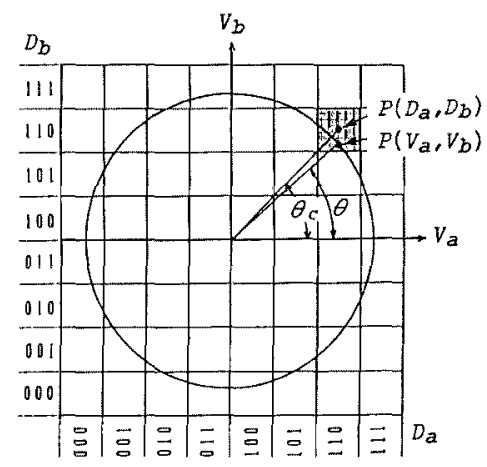

図2状態七ルの説明図

Fig. 2. An explanation of the status cell.

位相コードはエンコーダの 1 ピッチ内を $N$ 分割するので、 エンコーダの分解能を $N$ 倍し、1 $/ N K$ 回転とすることが できる。6ビットA／D変換器 2 個と、 $4 \mathrm{k}$ バイトROM

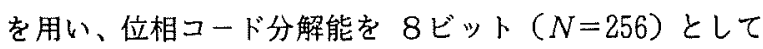
内挿システムを構成する。市販の $K=360$ の光学式ロータ リエンコーダを精密回転ステージを用いて等速回転させ、 このシステムを用いて検出した位相コードの一部を図 $3 に$ 示す。

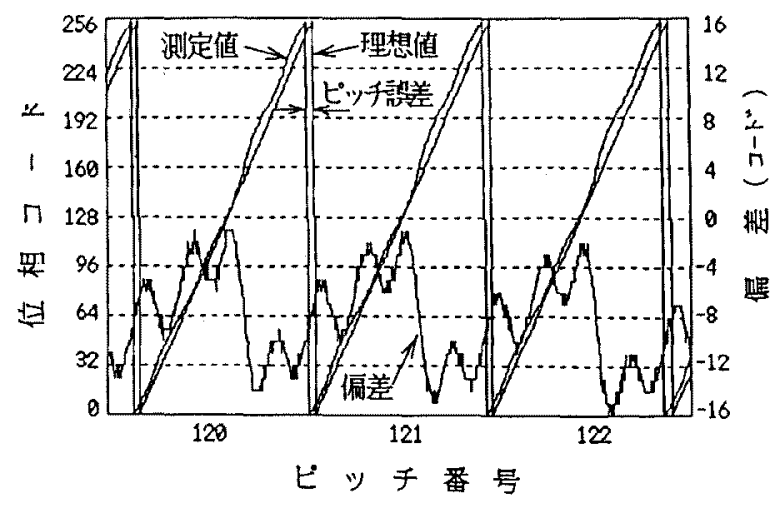

図3 位相コード出力例と理想值

Fig. 3. Example of measured and ideal phase code outputs.

位相コードは 256 が1ピッチ即ち電気位相角 $2 \pi$ オジア ンに対応する。等速回転であるから位相変化は直線的にな るべきであるが、検出位相コードの直線性は良くなく、ま た 4 ．で説明する理想直線から得られるピッチと比較する と、図4に示すようにロータリエンコーダのピッチ自体も 正確ではないことも分かる。

図4において、横軸はロータリエンコーダの軸の回転角 度、縦軸は理想ピッチとの誤差を角度で表している。 


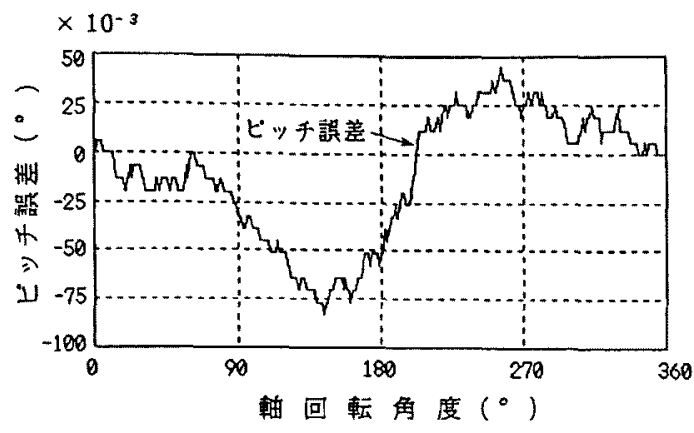

図4ピッチ誤差の測定例

Fig. 4. An example of the pitch detecting error.

ピッチ誤差は最大 0.08 ・であり、ピッチ内の歪とを合 わせると約 $0.10^{\circ}$ の誤差が 2 相正弦波信号に存在するこ とになる。したがって、結果として得られる位相コードは エンコーダの軸の回転角度に正確に対応せず、スケールピ ッチ内の分割数を大きくしても測定精度の向上は期待でき ない。

\section{3.コード補正法}

ロータリエンコーダの回転角度と位相コードを正確に対 応させるためのコード補正法について述べる。ロータリエ ンコーダの 2 相正弦波から得られる位相コード出力を補正 するための最む正確な方法は、本システムの各コード出力 に対し、正確な角度測定を行い校正を行うことであるが、 ここではこのような校正法によらない補正方法を提案する。

ロータリエンコーダは 2 相正弦波信号および 1 回転中一 定の角度で 1 回基準パルスを出力する。このロータリエン コーダを等速回転させ、基準パルスから次の基準パルスま
での 2 相正弦波信号を一定サンプル時間 Tでサンプルする ことにより、エンコーダ 1 回転分の位相コードデータを得 ることができる。1ピッチの位相コード数は 2 個である ので総位相コード数は $2^{n} K$ となる。これはロータリエン コーダを等速回転させて得られたデータであるから、図 5 に示すようにこの1回転分の総ピッチ間を直線で結んだも のは正しい回転角度を与えることになる。したがって、こ の直線を位相コードの理想值線とし、回転角度の測定にお いて得られた位相コードに理想直線上の值を対応させるこ とにより補正を実施する。

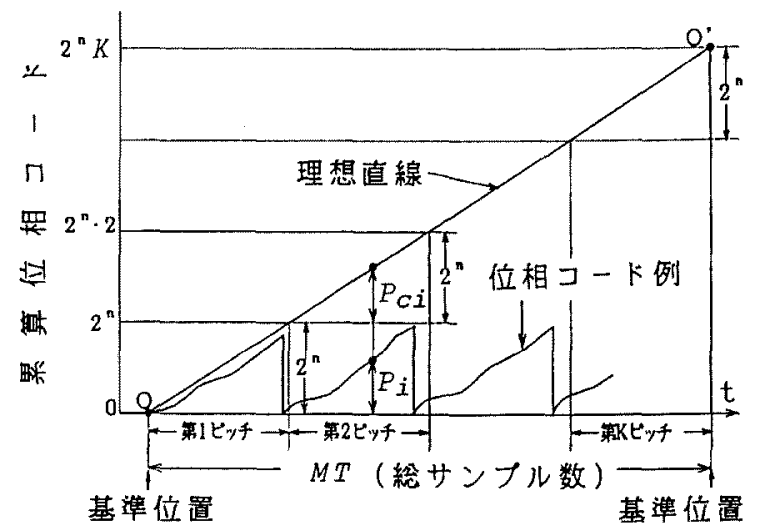

図5補正值算出原理

Fig. 5. Method of obtaining the Compensated Code.

たとえば、図5のエンコーダの第 2 ピッチにおいてエン コーダから得られる位相コード $P$ ；に対しては $P_{c ｝ \text { を正し }$ い位相コードとする。ここで総サンプル数を $M$ とすると、 第 $i$ サンプル時点の位相コードP；に対㐫する正しいと考 えられる位相コード $P$ G 仙 (5) 式で与えられる。

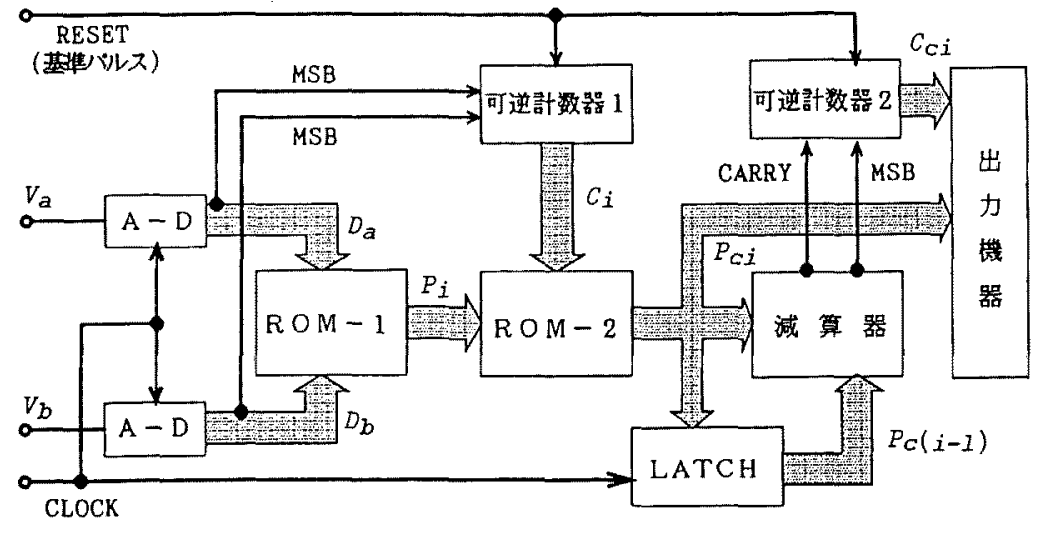

図6 ロータリエンコーダ用内捕システムの構成

Fig. 6. An interpolation system with compensation for rotary encoders.

$$
P_{C j}=\left[\left(\frac{2^{n} K}{M}\right) i-2^{n} C_{C i}\right]
$$

電学論C, 114 巻 1 号, 平成 6 年
ただし、［］はガウス記号である。 ここでC。性基準位置から数えたピッチ数で、M>2 ${ }^{n} \mathrm{~K}$ 
であれば、全てのP，について $P_{c i}$ を得ることができる。 エンコーダ自体のビッチ数は、A $/ \mathrm{D}$ 変換器出力のMS Bパルスを可逆計数器で計数することにより C，として得 られる。(5) 式で得た $P$ oiをROMのアドレス $2{ }^{n} C_{i}+P$ に書き込んでおけば、可逆計数器の出力 $C$ ，と実際に測定 された位相コード $P$ ；から直ちに正しい位相コード $P_{C}$ を 知ることができる。そしてこの $P_{C} ＼mathrm{~ と ~} C_{C} ；$ から、エンコ 一ダの基準パルス発生点を基準位置とする補正された絶詨 角度を得ることができる。図6に提案するロータリエンコ ーダ用内挿システムの棈成を示す。

\section{4. 位相コード出力の再現性}

位相コードの補正が正しく行われるためには、ロータリ エンコーダの 2 相正弦波出力に再現性がなければならない。 そこで、以下に述べる方法で再現性についての検討を行っ た。最初に、ロータリエンコーダとそれを回転させる回転 ステージとの接続位置や、ロータリエンコーダの回転方向 などの条件を変えないで 1 回転分の位相コードデータを 2 回測定し、両者の測定位相コードデータを比較する。次に、 回転方向を変えて位相コードデータを測定し、回転方向に よる位相コードデータの比較を行った。

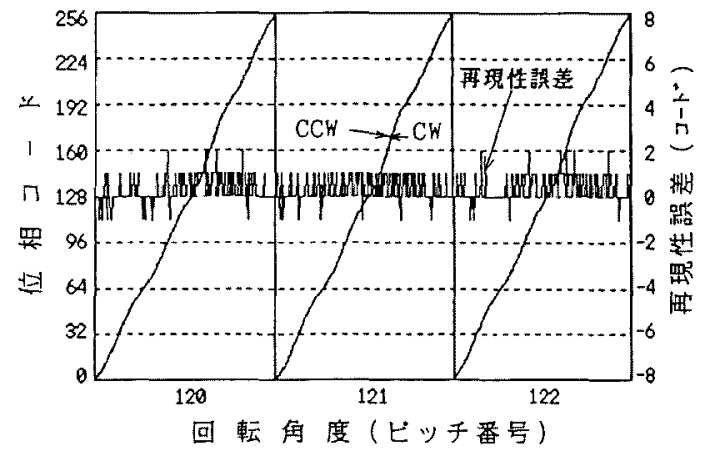

図7回転方向と位相コード出力

Fig. 7. Phase code for $\mathrm{CW}$ and CCW rotation.

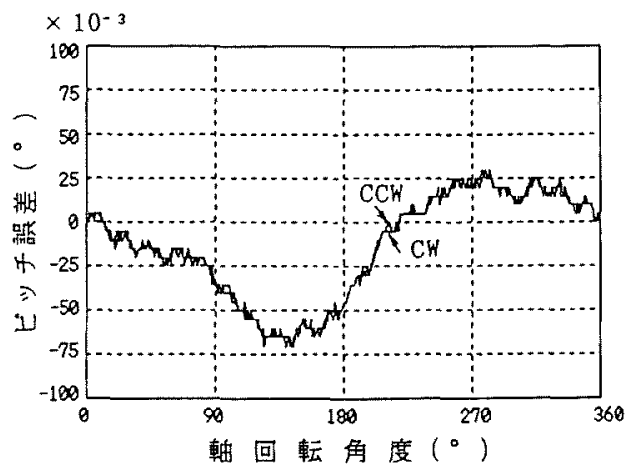

因8回転方向によるピッチ誤差

Fig. 8. Pitch error for $\mathrm{CW}$ and $\mathrm{CCW}$ rotation.
回転方向を変えた場合の位相コードデータの比較の一部 を図 7 に、また全周分のピッチ誤差の比較を四8にそれぞ れ示す。図7から、同一方向に回転させた場合の位相コー ド出力の再現性は结ぼ士 1 コード以下であり、最大でも土 2 コード以下であることが分かる。

これをロータリエンコーダ軸の回転角度に換算すると、 それぞれ $\pm 0.0039^{\circ} ， \pm 0.0078^{\circ}$ 以下となる。

また、ピッチ䛊差の再現性は、ロータリエンコーダ軸の 回転角度にして $0.005^{\circ}$ 以下であった。なお、同一回転 方向の場合の再現性は、回転方向を変えた場合より良好で、 これらのことから再現性には問題はないといえる。

次に、ロータリエンコーダと回転ステージとの相対位置 が $90^{\circ}$ つつ異なる4通りの位置で固定し、4種類の位相 コードデータを測定した。そのピッチ誤差の比較を図 $9 に$ 示す。この図から、ロータリエンコーダと回転ステージの 接続位置を変えると、その位相コード出力の再現性はなく なることが分かる。

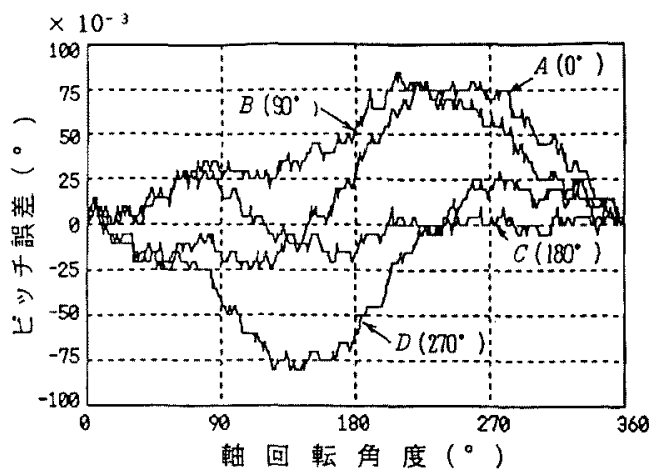

四9接続位置によるピッチ誤差の比較 Fig. 9. Pitch error due to the mechanical coupl ing.

また、接続位置が同じであってもロータリエンコーダを 回転ステージに固定するボルトの締め付け具合を変えるこ とにより、ピッチ誤差の発生状態が変化することも実験に より確認した。つまり、ロータリエンコーダを使用する状 態に固定してから、3．の手順でコード補正用データを取 得する必要がある。

このピッチ誤差の原因をロータリエンコーダの回転軸と そのメインスケールとの偏心およびロータリエンコーダの 回転軸と回転スデージとの偏心の合成されたものであると 仮定すると、前者を原因とするピッチ誤差は、上記のよう に回転ステージとの接続位置を変えても変わらないが、後 者を原因とするピッチ䛊差は、ロータリエンコーダと回転 ステージの接続位置を変えると、接続位置の変化分だけそ の位置が移動すると考えられる。

ここで、メインスケールの偏心を原因とするピッチ誤差

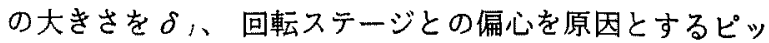




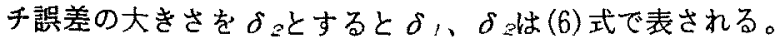

$$
\left\{\begin{array}{l}
\delta_{1}=A s \text { in }(x+a) \\
\delta_{2}=B \text { s in }(x+b+c)
\end{array}\right.
$$

上式で、 $x$ はロータリエンコーダの基準位置を $0^{\circ}$ とす る回転角度、 $a 、 b$ 基準位置と各偏心との相対角度、 $c$ はロータリエンコーダと回転ステージとの相対角度である。 A、Bは偏心を原因とするピッチ誤差の最大值で次式で与 えられる。

$$
A=\tan ^{-1} \frac{\nu}{r}, \quad B=\tan ^{-1} \frac{\nu^{\prime}}{r} \cdots(7)
$$

ただし、レ、ん’は偏心量、「はメインスケールの半径

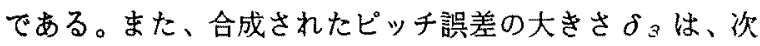
式で求められる。

$$
\delta_{3}=\delta_{1}+\delta_{2}
$$

$A=0.030^{\circ}, B=0.030^{\circ}, a=190^{\circ}, b=200^{\circ} \quad \zeta し た$ 時の $\delta_{3}$ の計算值を图 10 に示す。ここで、cとしては $0^{\circ}, 90^{\circ}, 180^{\circ}, 270^{\circ}$ のつの場合について求めた。

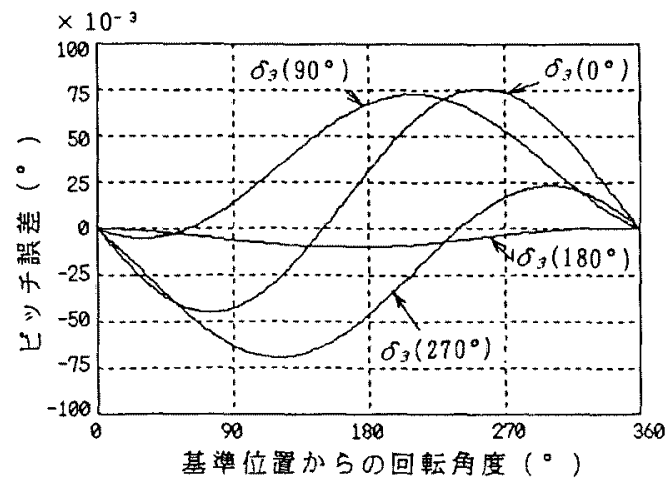

図10 ピッチ誤差シミュレーション波形 $(A=0.03, B=0.03, a=190, b=200)$ Fig. 10. Simulated pitch error.

図9の実測值と図 10 のシミュレーション結果がよく一 致することから、ピッチ誤差の原因はロータリエンコーダ の回転軸に対するメインスケールおよび回転ステージの偏 心であることが推定できる。また、(6) 〜 (8) 式から扁心 の方向、大きさを計算することができる。

\section{5 . 実験結果}

6 ビットA $\mathrm{A} / \mathrm{D}$ 変換器 $\times 2$ 、位相コード変換用 $4 \mathrm{k}$ バ イトROM、補正用 $64 \mathrm{k}$ バイトROM及び 360 進可逆計 数器 $\times 2$ を用い、8ビット分解能の内择システムを構成し た。図 11 に市販の $K=360$ (分解能 $1^{\circ}$ ) の光学式エン コーダの等速回転時の、図 3 と同じ回転軸位置における補 正された位相コード $P_{C}$ ，と理想直線からの偏差を示す。位 相コードで表した理想直線からの偏差は土2、回転角度に して土 $\left(7.8 \times 10^{-3}\right)^{\circ}$ 以内であった。これはエンコーダ自 体の分解能 1 をを約128 倍に向上させたことに相当する。

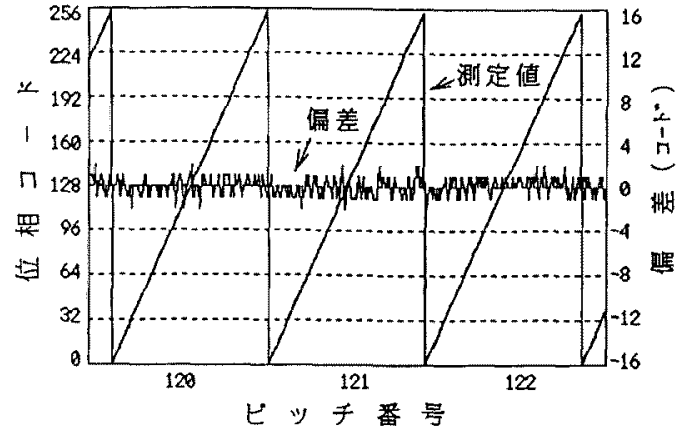

図 11 補正後の位相コード及び偏差

Fig. 11. Compensated phase code and deviation.

図 12 に補正前のピッチ及び補正㣪のピッチの直楾から 計算されるピッチからの偏差を示す。今回は補正用に $64 \mathrm{k}$ バイトROMを用いたため、補正範囲は 0〜 $255^{\circ}$ である が、その範国内でのピッチの偏差は $\pm\left(5.0 \times 10^{-3}\right)^{\circ}$ 以内 に収まっている。

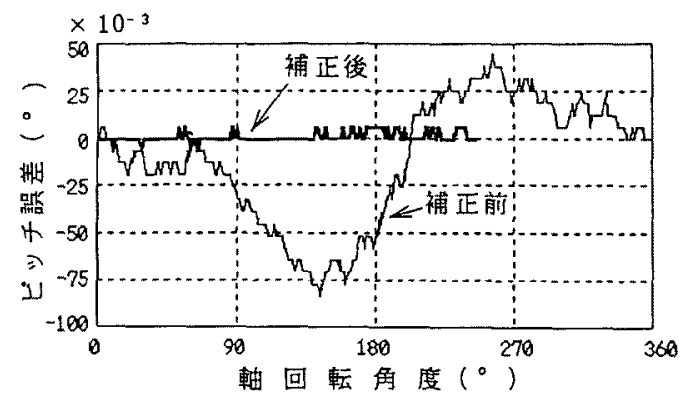

図 12 補正前後のピッヂ誤差の比較

Fig. 12. Error in pitch position before and after the compensation.

\section{6、まとめ}

ピッチ内の回転角度を絶対值式で計測するインクリメン タル型エンコーダの内挿法に、ピッチ間隔の誤差をも含め たコード補正を加えることによって、1ピッチ1/360 回転 の市販の光学式エンコーダの分解能および精度を 100 倍強 向上させることができた。また、ロータリエンコーダの角 度の検出はハードウェアのみで処理されるため、2相正弦 波出力を試作装置に入力してから補正された位相コードを 出力するまでに要するむだ時間は、サンプリング周波数を $2 \mathrm{MHz}$ としたとき $0.75 \mu \mathrm{s}$ となり高速処理が可能となった。 本方式は 2 相正弦波信号を出力する既設のインクリメン タル型エンコーダに適用でき、応答速度を損なうことなく その分解能を向上させることができる。

また、試作装置に䉍単な回路を付加することにより、回 
転角速度の検出も可能である。

(平成 5 年 4 月 22 日受付)

文献

（1）右近他：「多回転式絶対值エンコーダの開発」,電気学 会産業計測制御研究会資料, IIC-87-5, pp. 35-42 (1987.5)

（2）杉浦他：「正弦波エンコーダを用いた高分解能ディジ 夕ル速度検出法」, 電気学会産業計測制御研究会資料, IIC-87-4, pp. 25-34 (1987.5)

(3) K. Ishizuka et al., , "Development of a High Precision Rotary Encoder", Denshi Tokyo, No.30, pp. 67-69 (1991)

（4）大野他：「3600万パルスアブソリュートエンコー ダ」,精密工学会誌開発資料, Vol. 58, pp. 55-60（1992）

（5）松永:「高精密測定用光学式エンコーダ」, JSPE-5104, pp. 722-728 (1985)

（6）萩原他：「高分解能レーザ干渉変位計と速度計測」, 平 成元年電気学会全国大会論文集, No. 44

（7）萩原他：「コード補正によるロータリエンコーダの高 分解能化」, 平成 3 年電気学会全国大会論文集, No. 54

(8) N. Hagiwara et al. , "A Method of Improving the Resolution and Accuracy of Rotary Encoders Using a Code Compensation Technique", IEEE Trans. Instrum. Meas. , Vol. 38, pp. 482-485 (1989)
小倉 五十司 (非会員) 昭和 38 年 4 月 8 日生。

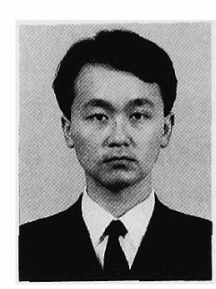

61 年 3 月防衛大学校卒業。

平成 5 年 3 月防衛大学校理工学研究科卒業。 同 4 月防衛庁海上幕僚監部勤務。

鈴木 義久 (正員) 昭和 9 年 11 月 15 日生。30年

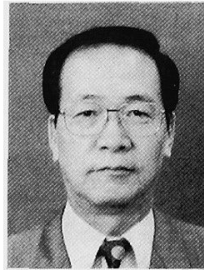

3 月東海高等通信工学校技術本科卒業。直 ちに船舶無線電信電話（株）入社。31年 5 月防衛大学校電気工学教室に勤務。3 6 年同助手。レーダによる反射断面積、距離、 速度の精密測定求よび防錆用塗膜の非破壊 劣化試験、自動計測などの研究に従事。

萩原述史 (正員) 昭和 12 年1 1 月 20 日生。3 5 年 3 月防衛大学校卒業。 44 年 3 月東京工 業大学理工学研究科博士課程修了。同 4 月 防衛大学校電気工学教室講師、5 1 年 4 月 同助教授、平成 2 年 4 月同教授。この間、 電子計測回路、光応用計測の研究に従事。 工学博士。 